\title{
Introduction: research on women in business and management
}

\section{Diana Bilimoria and Sandy Kristin Piderit}

The purposes of this handbook are to provide a forum for presentation of the current state of knowledge about women in business and management and to specify the directions for future research that will be most constructive for advancing the representation, treatment, quality of life and success of women who work in these fields. In this sense, we hope that the Handbook on Women in Business and Management will serve as a reference for recent advances in research and theory, informing both scholars and those with a general interest in the subject.

From the early days of inquiry into women and work (a collation of early research appeared in Larwood et al.'s (1986) Volume 1 of their Women and Work edited series) the topic of women in business and management has continued to garner interest by research scholars. A few specialized academic journals are devoted entirely to this and related topics of gender and work (for example, Equal Opportunities International, Gender, Work and Organization, Sex Roles, Women in Management Review), with special issues of these and other journals (for example, British Journal of Management, Journal of Organization Change Management), past and upcoming, focused on pertinent sub-topics such as women's career advancement, women and leadership, work-life integration, women corporate directors, and the gendering of work and organization. Within the past two decades, published research on women in business and management has mushroomed; several books and textbooks (for example, Padavic and Reskin, 2002; Parker, 2005; Powell and Graves, 2003; Smith, 2000; Vinnicombe and Colwill, 1995; Wirth, 2001) and edited volumes (for example, Burke and Mattis, 2005; Burke and Nelson, 2002; Ely et al., 2003; Davidson and Burke, 2000, 2004; Powell, 1999; Riger, 2000) compiling the research have been published in recent years.

Concurrent with the large volume of ongoing knowledge creation, dissemination venues for research on women in business and management have expanded. Most leading schools of business and management offer MBA and executive education coursework on topics relevant to the careers and effectiveness of women leaders, managers and executives, exposing tens 
of thousands of students annually to research findings about women in business and management. A vibrant and growing segment of the popular trade publications market pertains specifically to women's life and career development concerns within organizational workplaces (for example, Babcock and Laschever, 2003; Frankel, 2004; Kolb et al., 2004; Stanny, 2004). Finally, the subject of women in business and management has grown extremely popular within the general media and business press, with articles, surveys and report cards of various kinds appearing regularly in the public domain (for example Harvard Business Review, 2005; Catalyst, 2002, 2003a and b, 2005; Working Mother, 2005).

Yet, despite decades of ongoing inquiry, numerous outlets for knowledge creation, and widespread public interest, research on women in business and management remains a specialized field of study that appears not yet to have reached widespread mainstream acceptance as a scholarly field of inquiry within business and management disciplines. Our search of six leading business and general management academic journals (Academy of Management Executive, Academy of Management Journal, Academy of Management Learning and Education, Academy of Management Review, Administrative Science Quarterly, and Strategic Management Journal) revealed that of the 60 special issues, special sections, or special topic forums appearing in these journals over the last two decades, not one pertained specifically to the topics of women or gender in business and management. Similarly, while individual articles addressing these topics have been scattered throughout many of these six leading management journals, their proportions remain disturbingly low. A search of the keywords 'women', 'gender', 'sex' or 'diversity' in article titles, abstracts or subjects revealed that only 76 (out of a total of 2753) articles on these topics were published in these six leading business and management journals during the 10-year period from January 1996 to January 2006. That is, only 2.76 per cent of the articles published in the last 10 years in top academic business and management journals specifically related to women in business and management. Taken together, these statistics about special issues and individual articles published in the field's premier journals point to the failure of top-quality academic publication outlets to recognize and invite inquiry into this important issue, and suggest that scholars must rise to the challenge of improving their future research and theorizing about women in business and management so as to better qualify for publication in these top journals.

It appears that the statistics of published research on this subject oddly mirror the stark realities of the numbers of women in business and management: many in the larger field but few at the top. In 2002, when the percentage of women in the labor force was 59.2, women constituted 
46 per cent of the total US labor force and 38 per cent of the managerial and professional work force (US Department of Labor, 2004). Of the net new entrants into the workforce between 1994 and 2005, 62 per cent were projected to be women (Hudson Institute, 1997). Yet, the most up-to-date statistics indicate that women constitute only 15.7 per cent of Fortune 500 corporate officers (Catalyst, 2002), 13.6 per cent of Fortune 500 directors (Catalyst, 2003a), 11 per cent of corporate officers and 9 per cent of corporate directors of high-tech Fortune 500 firms (Catalyst, 2003b), and 9.9 per cent of Fortune 500 corporate officers in line jobs (Catalyst, 2002). Women hold only 7.9 per cent of Fortune 500 influential titles such as Chair, CEO, ViceChair, President, Chief Operating Officer, Senior Executive Vice-President and Executive Vice-President and are only 7.1 per cent of Fortune 500 Chief Financial Officers and only 5.2 per cent of Fortune 500 individuals who are their company's five most highly compensated officers (Catalyst, 2002). Only 3 per cent of corporate board directors (Catalyst, 2003a) and 1.6 per cent of Fortune 500 officers (Catalyst, 2002) are women of color. And most tellingly, only 1.4 per cent of Fortune 500 CEOs are women (USA Today, 2005).

It appears, thus, that the institutional inclusion of research on women in top business and management academic journals mirrors the prevailing gendered practices of our larger society. From the numbers cited above, we draw the unsettling conclusion that only token research on women appears at the premier levels of academic publication in business and general management. This is particularly troubling because business and management research and scholarship has the potential to lead in the betterment of the world of work, proactively charting courses that construct and communicate more effective solutions to everyday workplace realities. Without this progressive aspiration and function, scholarly research limits its vitality and usefulness for the real world, and falls short of its potential as the herald of constructive business and management change.

Simply said, to date our top-level academic research journals generally have not been proactive in addressing the realities facing women in business and management. We hope that this handbook serves as a call inviting future scholarship of the kind that improves the societal and work conditions and experiences of women in business and management. But at the same time, we would like to acknowledge that our hope is that the insights simultaneously offer the foundations for improved societal and organizational structures, policies and relational practices affecting all in business and management. Thus, by enhancing the knowledge base that improves the work and life situations of women, we hope this collection provides guidance that elevates the societal and organizational systems for all.

We organize the chapters in this compilation into four broad parts relevant to research on women in business and management. The first part describes 
the societal roles and contexts facing women in these fields. In this part, the authors identify different aspects of the pervasive gendering of work and organizations, expose the covert and subtle roles of assumptions, expectations and beliefs that constrain women in the workforce, and provide directions for a more liberating scholarship that has the potential to catalyze change.

In their chapter, Linda Dunn-Jensen and Linda Stroh address major myths and stereotypes, pervasive in the popular media, about women in the workforce. They provide research evidence to counter the prevailing myths that women are opting out of top-level jobs in greater numbers than men, women are not as willing as men to work hard for top spots in organizations, women are too passive to claim their just rewards in organizations, women don't want power, and women find there are more psychological and social rewards for staying home. They call for future research at the level of the underlying assumptions made about both women and work, to uncover the factors that perpetuate the media's adherence to inaccurate myths and stereotypes about women.

The chapter by Joy Beatty addresses the pervasive role of woman as 'other' in organizations and the process of women's identity creation in light of their symbolic outsider status in organizational life. Addressing women's invisible social identities and hidden stigmas in the workplace, she identifies three powerful assumptions engendering women as the other: organizations are genderless, organizations are bodyless, and organizations are sexless. She describes the main mechanisms by which women cope with this otherness (blending in to meet others' expectations or internalizing self-discipline and control), exploring the personal costs to women from either strategy of managing hidden stigmatized identities.

Caroline Gattrell and Cary Cooper's chapter proposes that the main causes of the stress experienced by women in business and management are structural and institutional; social attitudes and misplaced assumptions about the low work-orientation of women managers heighten their stress levels. These authors offer a social explanation for the continued existence of the glass ceiling by discussing the historical expectation that women should be mothers and homemakers, not work-orientated careerists. Their call to future research is not to narrowly determine the causes of stress for women in business and management (as these are well documented), but rather to find ways of constructing new social relations that promote and encourage working women.

In the fourth chapter of the first part, Marta Calás, Linda Smircich and Kristina Bourne call on future research on women's entrepreneurship to be more grounded in applications of feminist theory: to produce more relevant knowledge for a more just society, away from situations of women's and others' subordination. Their chapter portrays research on gender and 
entrepreneurship as fertile for imagining these social change possibilities. Relying on metaphoric illustration and feminist theorizing, they raise important questions for future research that address both who the woman entrepreneur is (and what kind of issues can be raised about her) and the gendering of entrepreneurship (addressing how knowledge production about women's entrepreneurship can catalyze improved social relations).

The second part of the handbook concerns research on specific career and work-life issues of women in business and management. In this part, the authors review research findings, recognize the complex intertwining and subtle nuances of women's careers and lives, caution against treating women or their careers as monolithic, and identify the shape and direction of future research on women's career and life development that takes into account their multiple responsibilities and commitments.

In his chapter on women's career advancement, Ron Burke provides an extensive review of influences on the career development and retention of professional and managerial women (including models of career development, work and career experiences, developmental jobs, developmental relationships, and opting-out). Highlighting a gap in the literature, his article also explores organizational initiatives most supportive of women's career development, particularly work-family balancing practices, alternative work arrangements, and talent development. Burke's article calls for future scholarship that recognizes the complexity of women's work lives, and which takes into consideration career changes as women age and change with multiple life roles.

In Chapter 6, Margaret Hopkins and Deborah O'Neil explore changing definitions of women's careers and career success. Paying attention to how women's careers and lives are confluent, they examine the myriad ways by which women perceive personal and professional success. Calling for research that acknowledges and celebrates the complexities of women's lives in contemporary society and that moves beyond traditional gendered constructions of career success, these authors challenge future scholarship to take on a more positive approach to women's careers and career success: to study what women are moving toward as opposed to what women are leaving, to understand how women self-determine and not passively accept their careers, to explore women's own definitions and experience of success in addition to those that are societally or organizationally mandated, and to identify the contributions made and not just the costs incurred by women's careers in business and management.

Helen Woolnough and Marilyn Davidson's chapter on mentoring as a career development tool addresses the roles of gender as well as race and ethnicity in formal and informal mentoring. They review research that describes the impact of gender and race/ethnicity on the availability, 
selection, type, amount and benefits of mentoring. In a valuable discussion of new alternative forms of mentoring such as peer mentoring, group mentoring and online mentoring, the authors call on future research to study these newer forms of mentoring. In raising awareness of the roles of women and black and ethnic minorities in mentoring relationships, the authors invite future research to question current workforce practices of demographically homogenous relationships, and preferences for informal and traditional dyadic mentoring.

The final two chapters of Part 2, by Mireia Las Heras and Tim Hall and by Sandy Piderit, address the quality of work-life in contemporary organizations. Both articles call for future research on work-life to promote newer constructions of integration and harmonization, which move away from traditional decomposition of work and life into separate entities. Both articles propound the well-being and satisfaction of the individual as the main career outcomes, not the objective success criteria (for example, salary, rank and promotions) so frequently utilized in the mainstream literature on career development. Drawing on the first years of career development, the Las Heras and Hall chapter suggests that integration of work and non-work is an outcome of adult development; that a person's growing selfawareness about extrinsic and intrinsic career goals can lead to psychological development and identity integration. Piderit's chapter cautions scholars not to perpetuate the view of work-life issues as problems that can be solved at the individual level with better choices, and calls for future research to open up societal assumptions regarding work-life quality.

Part 3 of the handbook, 'Organizational processes affecting women in business and management', tackles the organizational and human resource policies and practices, both positive and negative, which influence the effectiveness and success of women in organizations. In the first chapter of this part, Laura Graves and Gary Powell review theories and research evidence regarding the effects of sex, sex similarity, and sex diversity in ongoing mixed-sex teams. They consider how key factors associated with the contexts and situations in which mixed-sex teams operate may influence the nature and extent of each type of effect. These authors recommend a comprehensive future research program that examines the influence of a wide array of situational factors (for example, whether the context emphasizes or de-emphasizes sex, the team's overall demographic composition, the team's longevity, the gender orientation and structure of the team's task, the gender composition of the larger organization and its top management, and the organization's culture) on individual-level and team-level effects.

Chapter 11, by Diana Bilimoria, Lindsey Godwin and Deborah Zelechowski, draws attention to the subtle organizational processes and practices that facilitate or hinder women's career success and advancement 
in business and management. Building the case for why women's career advancement is uniquely different from men's in organizations, these authors develop a framework for women's career advancement that includes the characteristics, skills and networks of individuals (personal influence) and the friendliness of the environment (social inclusion). Overall, they recommend that future research take into account the myriad organizational situations of women in business and management, and call for finer-grained understanding to emerge about how women's career advancement patterns differ in these situations.

Chapter 12, by Alison Konrad, addresses how diversity-related practices (of recruitment, selection, training and development, career progression and retention) in organizations can promote women's careers in business and management. Like the other two chapters in this part, Konrad urges future scholarship to be more cognizant about diversity among women. She reviews the empirical literature on the types of human resource management practices with career outcomes for women, the factors linked with higher adoption levels of diversity-related practices, and the relationship between diversity and organizational performance. Her recommendations for future research call for research to examine the strategic effects of diversity and diversity training, and to consider their impacts on a wide variety of women.

Part 4 of the handbook pertains specifically to the role of women as leaders in business and management. The three chapters in this part all draw attention to the many opportunities and challenges facing women in leadership positions. They raise questions about how research can spur the creation of better societal and organizational policies and practices for the advancement to and success of women in leadership roles in business and management.

Alice Eagly and Mary C. Johannesen-Schmidt's chapter provides an extensive review of the literature on leadership styles, addressing questions such as: why would we expect women's and men's leadership styles to be similar or different? How do women and men compare on task-oriented and interpersonally oriented leadership styles, on autocratic versus democratic styles, and on transformational, transactional and laissez-faire styles? Their review concludes that the preponderance of evidence suggests small, but possibly consequential, differences in how women and men lead: women lead with an especially collaborative, interactive, participative style and that this style produces female advantage.

Val Singh, Sue Vinnicombe and Siri Terjesen's chapter addresses the international representation of women at the highest levels of corporate leadership and governance: women corporate board directors. Their indepth review covers the statistics on women corporate directors and the varied approaches used in countries such as the USA, UK and Scandinavia 
to address the issue of lack of female representation on corporate boards: liberal, coercive and consensus methods. The authors call on future research to build the business case for women corporate directors more thoroughly, especially with regard to their impact directly on board performance, and indirectly on corporate performance.

The final chapter of this part and the handbook, by Nancy Adler, pertains to women ascending to international leadership roles. Her forward-looking review suggests that the scarcity of women at the top is no longer an option for business and management, especially for engendering the necessary global and societal improvements to create a world worthy of bequeathing to future generations. In this regard, she exposes the myths that women don't want international careers, that foreigners' prejudice makes it impossible for women to succeed internationally, and that dual-career marriages create insurmountable obstacles for women working abroad. Her essay holds that the traditional masculine-dominated American style of organizing is losing ground in the global workplace, that women are well equipped to take on the leadership of global institutions, and that corporations worldwide would do well to understand that the most effective leadership comes from both women and men.

\section{References}

Babcock L. and S. Laschever (2003), Women Don't Ask: Negotiation and the Gender Divide, Princeton, NJ: Princeton University Press.

Burke, R.J. and M.C. Mattis (eds) (2005), Supporting Women's Career Advancement: Challenges and Opportunities, Cheltenham, UK and Northampton, MA: Edward Elgar.

Burke, R.J. and D.L. Nelson (eds) (2002), Advancing Women's Careers, Oxford, UK: Blackwell Publishing.

Catalyst (2002), 'Census of women corporate officers and top earners', www.catalyst.org/files/ fact/COTE $\% 20$ Factsheet $\% 202002$ updated.pdf.

Catalyst (2003a), 'Census of women board directors', www.catalyst.org/files/fact/ WBD03factsheetfinal.pdf.

Catalyst (2003b), 'Bit by bit: Catalyst's guide to advancing women in high tech companies', www.catalyst.org/files/fact/BitbyBitfactsheetfinal.pdf.

Catalyst (2005), 'Women "take care", men "take charge": stereotyping of US business leaders exposed', catalystwomen.org/files/full/Women $\% 20$ Take $\% 20$ Care $\% 20 \mathrm{Men} \% 20 \mathrm{Take} \% 20 \mathrm{Ch}$ arge.pdf.

Davidson, M.J. and R.J. Burke (eds) (2000), Women in Management: Current Research Issues Volume II, London: Sage.

Davidson, M.J. and R.J. Burke (eds) (2004), Women in Management Worldwide: Facts, Figures, and Analysis, Aldershot, Hants, England; Burlington, VT: Ashgate.

Ely, R.J., E.G. Foldy, M.A. Scully and the Center for Gender in Organizations, Simmons School of Management (eds) (2003), Reader in Gender, Work, and Organization, Malden, MA: Blackwell Publishing.

Frankel, L.P. (2004), Nice Girls Don't Get the Corner Office: 101 Unconscious Mistakes That Women Make that Sabotage their Careers, New York: Warner Business Books.

Harvard Business Review (2005), Harvard Business Review on Women in Business, Boston, MA: Harvard Business School Publishing. 
Hudson Institute (1997), Workforce 2020: Work and Workers in the 21st Century, Washington, DC: Hudson Institute.

Kolb, D.M., J. Williams and C. Frohlinger (2004), Her Place at the Table: A Woman's Guide to Negotiating Five Key Challenges to Leadership Success, San Francisco: Jossey-Bass.

Larwood, L., A. Stromberg and B. Gutek (eds) (1986), Women and Work, Newbury Park, CA: Sage.

Padavic, I. and B. Reskin (2002), Women and Men at Work, 2nd edn, Thousand Oaks, CA: Sage, Pine Forge Press.

Parker, P.S. (2005), Race, Gender and Leadership: Re-envisioning Organizational Leadership from the Perspectives of African American Women Executives, Mahwah, NJ: Lawrence Erlbaum.

Powell. G.N. (ed.) (1999), Handbook of Gender and Work, Thousand Oaks, CA: Sage.

Powell, G.N. and L.M. Graves (2003), Women and Men in Management, 3rd edn, Thousand Oaks, CA: Sage.

Riger, S. (ed.) (2000), Transforming Psychology: Gender in Theory and Practice, Oxford and New York: Oxford University Press.

Smith, D.M. (2000), Women at Work: Leadership for the Next Century, Upper Saddle River, NJ: Prentice Hall.

Stanny, B. (2004), Secrets of Six-Figure Women: Surprising Strategies to Up Your Earnings and Change Your Life, New York: HarperBusiness.

USA Today (22 December 2005), Not-so-good year for female CEOs, www.usatoday.com/ money/companies/management/2005-12-22-women-ceos-usat_x.htm.

US Department of Labor (2004), Bureau of Labor Statistics, www.dol.gov/wb/stats/main. htm.

Vinnicombe, S. and N.L. Colwill (1995), The Essence of Women in Management, London and New York: Prentice Hall.

Wirth, L. (2001), Breaking through the Glass Ceiling: Women in Management, Geneva: International Labour Office.

Working Mother (2005), '100 best companies for working mothers', Working Mother Media Inc., New York, www.workingmother.com/100BEST_2005.html. 
Diana Bilimoria and Sandy Kristin Piderit - 9781847204134 Downloaded from PubFactory at 04/25/2023 11:52:30PM 